\title{
ATH AS A FILLER OF VINYLESTER RESIN
}

\author{
DESWAN $^{1}$ and DJOKO SETYANTO ${ }^{2}$ \\ ${ }^{1}$ Student, Master of Mechanical Engineering, Faculty of Engineering, Atma Jaya Catholic \\ University of Indonesia, Jalan Jenderal Sudirman, Jakarta, Indonesia \\ ${ }^{2}$ Associate Professor, Department of Mechanical Engineering, Faculty of Engineering, Atma Jaya Catholic
}

University of Indonesia, Jalan Jenderal Sudirman, Jakarta, Indonesia

\begin{abstract}
The aim of this research is to evaluate the possibility of using Alumina Tri-Hydrate (ATH) as a filler of vinyl ester resin in the production process of Glass Fiber Reinforced Plastic (GFRP) tanks. GFRP material sample consists of two layers, namely chemical barrier layer and structure layer. The chemical barrier layer is composed of surfacing veil and chopped strand mat 300 using pure vinylester resin (fiber/ resin weight ratio 30/70). The structure layer consists of 2 layers, namely the structure layer which is composed of chopped strand mat 450 and woven roving 600 using pure resin. The structure layer is composed of roving 2400 long yarn using matrix containing ATH (fiber/ matrix weight ratio 70/30). Variations in the matrix used consist of compounds with a percentage of the weight of the ATH to vinylester resin that is 0/100; 10/90; 15/85; 20/80 and 25/75. Physical properties namely density and water absorption and mechanical properties namely tensile strength were observed from all of the samples. The morphology of the cross section of sample pieces was observed by SEM. Data from the test results show that ATH has the potential to be used as a matrix in the structural layer of the winding process during tank production because both physical and mechanical properties show acceptable results.
\end{abstract}

KEYWORDS: GFRP, filler, ATH, Vinylester, Tensile, Density, Water Absorption

Received: May 20, 2020; Accepted: Jun 10, 2020; Published: Jul 11, 2020; Paper Id.: IJMPERDJUN2020281

\section{INTRODUCTION}

The use of modern composite materials has been used since the time of the Second World War (1939-1945), which at that time was used in the aircraft industry. This is because the composite material has the properties of corrosion resistant and resist to damage due to fatigue [1]. Composite is a combination of two or more different parts, so a material that has two or more materials or different constituent phases can be considered as a composite material (fiber and matrix /polymer) [2]. Polymers or resins are divided into two, namely thermoplastic resins and thermoset resins. Thermoplastic resins include polyethylene, polystyrene, polycarbonate and thermoset resins include epoxy resins, melamine resins, phenol resins, polyester resins and vinyl ester resins. Resins commonly used in GFRP are thermoset resins [1-3]. Glass Fiber Reinforced Polymer (GFRP) has been used for many applications such as fiberglass vessels, pressurized tanks and parts of aircraft [1]. GFRP has been used in the chemical and petrochemical industries has since the 1970s in the world, then developed in the middle of 1980s [4]. In Indonesia, GFRP materials have begun to be used in the construction sector since 1975 and the resin used in the process of making chemical and structural layers in chemical tanks is always the resin without a compound of fillers [5].

GFRP is a material commonly used for chemical tanks, which is a combination of polymer matrix 
(thermoset resin) and glass fiber. Both are used simultaneously in the tank layer as in the tank body (shell), the top of the tank (top) and the bottom of the tank (bottom) [6]. Guidelines for designing the body /shell of the atmospheric pressure GFRP tank are found in the ASTM D3299-00 standard [7]. In addition, it can also use BS 4994 standard in terms of GFRP tank design starting from the body (shell), cover (cover), flange, connection, fabrication methods, inspection and testing [8]. The inside of the tank is designed as a protective layer against chemicals (chemical barrier) called a chemical layer, where the composition of this layer consists of a thin layer of resin (resin rich layer), a layer of tissue (surfacing veils) and a layer of random fibers (chopped strand mat) [9]. The process of making chemical barrier is done manually (hand lay-up), then the layer after the chemical layer is a structural layer. Structural layer is the layer that gives the strength of the GFRP tank to the pressure from the tank. This composition layer consists of a layer of random fibers (chopped strand mat), a layer of woven fiber (woven roving) in which the manufacturing process uses a hand lay-up method, and a layer of unidirectional fiber (roving) in which the manufacturing process uses the method automatically with a rolling machine (filament winding machine) [4]. For more details see figure 1.

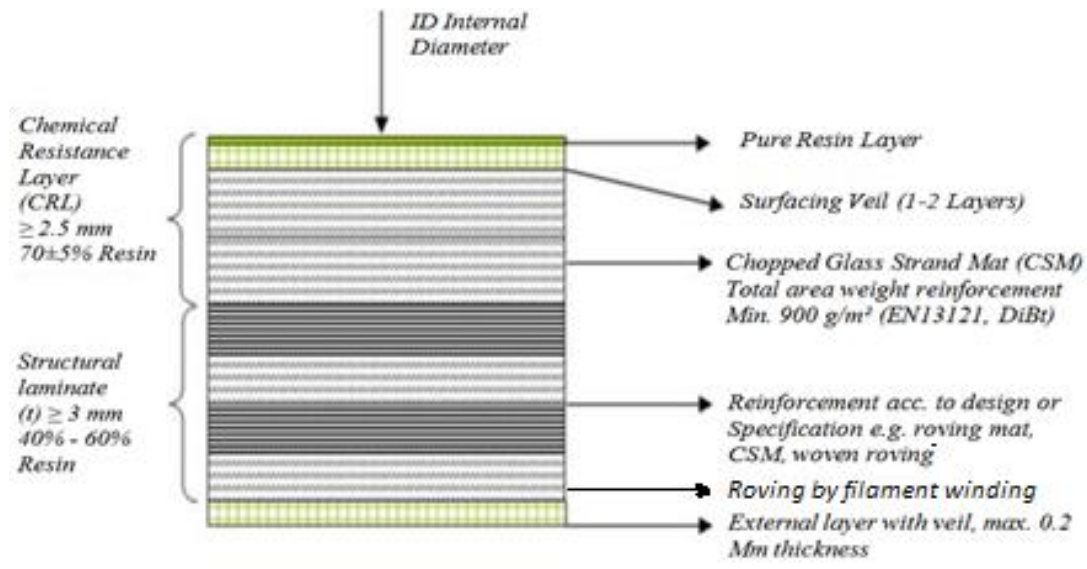

Figure 1. The arrangement of layers in the GFRP tank [9]

The most important thing in the manufacture of chemical storage tanks and chemical process tanks made from GFRP is chemical resistance. Therefore, the chemical layer must use a resin without a compound of fillers [10], while for the structure layer which serves as a support for the strength of the tank so as not to break due to pressure from the tank, should be able to use resin with a compound of filler in the body structure layer of the GFRP tank [5]. The use of fillers as compound in resin matrix continues to increase in the GFRP industry. This is because the fillers not only reduce overall production costs, but also provide performance improvements that might not be achieved with reinforcing fibers and resin matrix [3].

In Indonesia, GFRP tank manufacturing company in the Tangerang area, by name PT Diwan Budi Perkasa use $170,000 \mathrm{~kg}$ vinylester resin per year. The composition for the manufacture of chemical layers, the tanks are around $30 \%$ of the total weight of the resin used, meaning that as much as 51,000 $\mathrm{kg}$ of resin and the remainder are used for making structure layers as much as $119,000 \mathrm{~kg}$ of resin. Using filler in resin to make a chemical tank structure layer by replacing the composition of the resin weight in the filament winding structure layer in the tank with the filler weight composition can get savings in the use of resin [5]. Therefore, investigation of GFRP with ATH filler on physical and mechanical properties is necessary, especially to find out effect ATH as filler in vinylester resin, which will be applied to the chemical GFRP tank structure layer by filament winding method. Investigations were carried out to find the value of physical 
properties (density and water absorption) and mechanical properties (tensile strength) of GFRP then observe using SEM morphology.

This is supported by research studies that have used alumina as a filler in the resin, such as: the tensile strength significantly increased for the bisphenol-A epoxy resin modified with $5 \mathrm{wt} \%$ and $7 \mathrm{wt} \%$ of $50 \mathrm{~nm}$ particles alumina $\left(\mathrm{Al}_{2} \mathrm{O}_{3}\right)$ [11]. The tensile, flexural, impact, abrasion loss behaviours of coir polyester composites (UPR matrix natural green husk coir fiber and UPR matrix) were significantly influenced by the addition of aluminium oxide (alumina) in the resin system [12]. The addition of $\mathrm{Al}_{2} \mathrm{O}_{3}$ (alumina) filler has better young's modulus compared to other fillers (molybdenum disulfide/ $\mathrm{MoS}_{2}$ and titanium oxide/ $\mathrm{TiO}_{2}$ ) that filled in polyvinyl ester composite[13]. The complete physical and mechanical properties evaluation shows that alumina tri-hydrate is the best filler compared to the others (calcium carbonate and talc) as a filler material for Unsaturated Polyester Resin (UPR) matrix of Fiberglass Reinforced Plastic (FRP) composite roofing sheets [14]. ATH be effectively used to increase fire resistance and can effect on mechanical properties of Glass Fiber Reinforced Polymer (GFRP) material (made from orthophthalic resin as a matrix and E-glass chopped strand mat/ CSM as a reinforcement) based on compression, tension, shear and flexural [15]. The addition of ATH or montmorillonite (MMT) or combination of both on the GFRP composite (made from orthophthalic unsaturated polyester/ UP resin as a matrix, than chopped strand mat CSM 200 and woven roving WR 200 as a reinforcement) causes decrease in flexural strength and with increased ATH loading causes an increase in elastic modulus [16]. These studies are able to be used as a reference in the study of the effect of ATH fillers on vinylester resin.

\section{MATERIALS AND METHODS}

The flow chart of research activity design is illustrated in figure 2. GFRP composite material was made from vinylester resin, Glass Fiber (GF), and Alumina Tri-Hydrate (ATH). Vinylester F 013 resin of AOC was used as a matrix. MEPOXE Methyl Ethyl Ketone Peroxide (MEKP) as much as 1.25 vol \% of the resin was used as an initiator and Cobalt $6 \%$ Swanchor 1360 as much as 0.1 vol \% of the resin was used as an accelerator for the composite curing process. Surfacing veils SV 30 of commercial C-glass glass fiber of Chemtex, chopped strand mat CSM 300 of commercial E-glass glass fiber of Jushi were used as chemical layer reinforcement in the composite with pure resin. Chopped strand mat CSM 450 of commercial E-glass glass fiber of Jushi and woven roving WR 600 of commercial E-glass glass fiber of Jiangsu were used as structure layer reinforcement in the composite with pure resin. And roving (RV 2400) of commercial E-glass glass fiber of Jushi was used as structure layer reinforcement in the composite with resin containing ATH. The ATH with H-WF 15A brand was used as a filler.

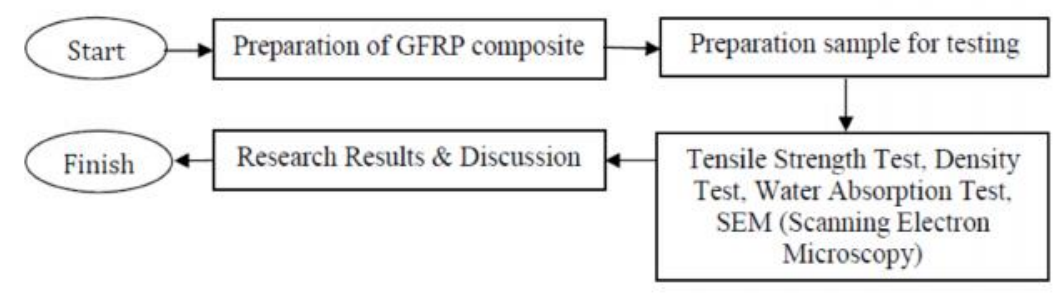

Figure 2. Research Activity Design Flow Chart.

The GFRP material samples on a long fiber yarn layer in this research are shown in Table 1. The Glass Fiber (GF) configuration of all samples were SV 30 (1 plies) + CSM 300 (2 plies + pure resin, CSM 450 (3 plies) + WR 600 (2 plies) + pure resin, RV 2400 (5 plies) + pure resin (sample 1), and for RV 2400 (5 plies) + resin that contain ATH are used in 
sample 2, 3, 4, and 5 (see figure 4b). The GFRP composite material was removed from the mold and then it was cut according to the sample dimensions. For Density test, it is as per ASTM D 1622-14 [17], for Water absorption test, it is as per ASTM D 570-98 [18], and for Tensile strength test, it is as per ASTM D 638-00 [19].

Table 1. The Variation of GFRP Material Samples on a Long Fiber Yarn Layer

\begin{tabular}{|c|c|c|c|}
\hline \multirow{2}{*}{ Sample Number } & \multirow{2}{*}{ Type of composite } & \multicolumn{2}{|c|}{ Weight fraction (wt\%) } \\
\cline { 3 - 4 } & & VE & ATH \\
\hline 1 & GFRP + 0\% ATH & 100 & 0.0 \\
\hline 2 & GFRP $+10 \%$ ATH & 90 & 10 \\
\hline 3 & GFRP $+15 \%$ ATH & 85 & 15 \\
\hline 4 & GFRP $+20 \%$ ATH & 80 & 20 \\
\hline 5 & GFRP $+25 \%$ ATH & 75 & 25 \\
\hline
\end{tabular}

The density and water absorption properties of GFRP were obtained from the results of tests conducted as per ASTM D 1622-14 and ASTM D 570-98 testing standard. Density testing was carried out within 15 days and water absorption testing was carried out within 7 days and each sample taken was at 10 pcs specimen. SEM morphology was carried out by referring to the sample portion on the longitudinal side in the direction of the reinforcing fiber with a magnification of 250x, 500x, and 1000x and the resulting image is a Secondary Electron Image (SEI). Each sample taken is best viewed and it is done for 5 samples (see table 2). The entire test was conducted at the Polymer Technology Center, BPPT, Indonesia.

Table 2. Water Absorption, Density test Conditions, and Morphological Analysis of SEM

\begin{tabular}{|c|c|c|}
\hline Type of Testing & Testing Parameters & Testing Conditions \\
\hline \multirow{4}{*}{$\begin{array}{c}\text { Water Absorption } \\
\text { Testing }\end{array}$} & Testing Standard & ASTM D570-98 (2010) \\
\hline & Test Equipment & Waterbath \\
\hline & Test Temperature & $23^{\circ} \mathrm{C}$ \\
\hline & Duration & 24 hour \\
\hline \multirow{4}{*}{ Density Testing } & Testing Standard & ASTM D1622-14 \\
\hline & Test Equipment & Sartorius balance \\
\hline & Pre condition & Temperature $23,0^{\circ} \mathrm{C}$, Humidity $50 \%$ \\
\hline & Test Temperature & $22,4^{\circ} \mathrm{C}$ \\
\hline \multirow{6}{*}{$\begin{array}{l}\text { Morphological } \\
\text { Analysis }\end{array}$} & Testing Standard & SEM \\
\hline & Test Equipment & JEOL JSM-6510LA \\
\hline & Magnification & $250 x, 500 x$ dan $1000 x$ \\
\hline & \multirow{2}{*}{ Testing Condition } & Voltage : $20 \mathrm{kV}$ \\
\hline & & Coating : platina \\
\hline & Type image & Secondary electron image(SEI) \\
\hline
\end{tabular}

The tensile strength properties of GFRP were obtained from the results of tests conducted as per ASTM D 638-00 testing standard. The tensile testing machine used in this test is the Hung Ta brand universal testing machine, the HT-9501 type with a capacity of 50,000 kgf. There are 10 pcs of test specimens for each sample, so in total, there are 50 pcs of test specimens which are subjected to tensile testing. The duration of testing is 1 hour for each sample, so the total is about 5 hours for testing 5 samples (see figure 3 and figure 4a). This test was carried out in the Material Characterization and Engineering Laboratory of the Mechanical Engineering Study Program at Atma Jaya Catholic University of Indonesia, Jakarta, Indonesia. 


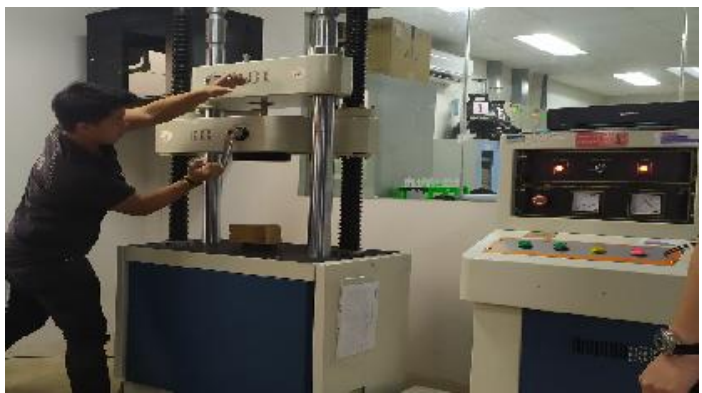

(a)

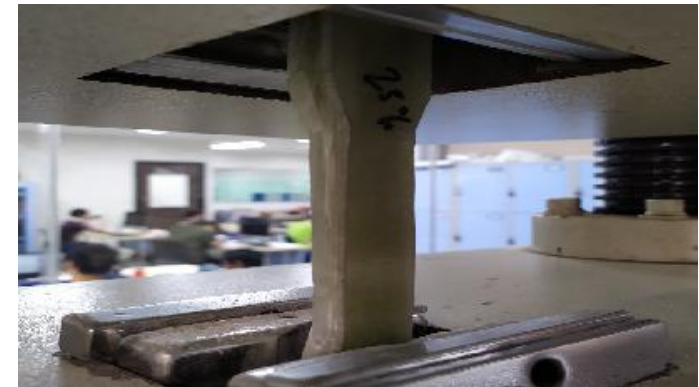

(b)

Figure 3. Testing Process: (a) Tensile Strength Test Machine and (b) Specimen in Tensile Strength Machine.

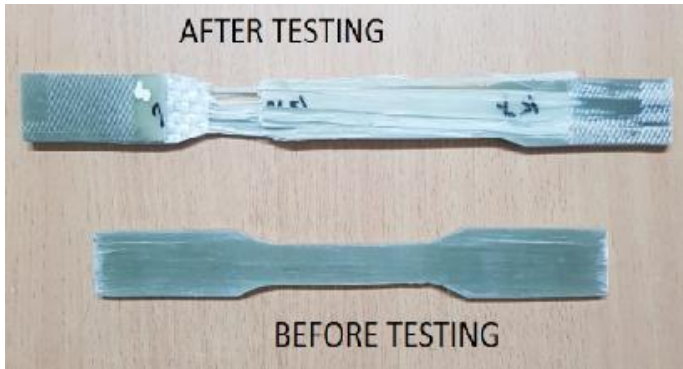

(a)

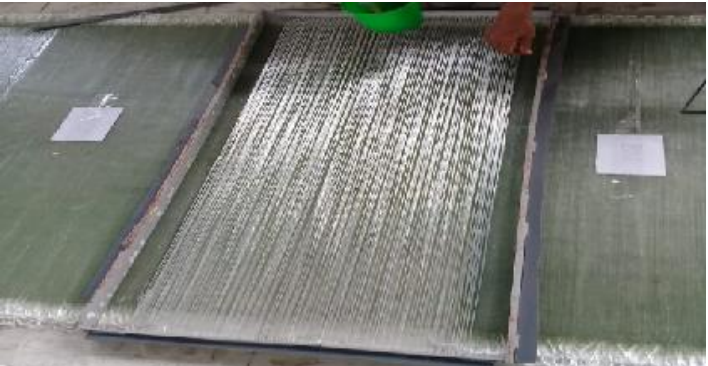

(b)

Figure 4. (a) Tensile Strength Test Specimen and (b) Sample Preparation.

\section{RESULTS AND DISCUSSIONS}

The results of SEM morphological analysis with magnification of 250x, 500x and 1000x clearly show the ATH content in each test sample. For samples without filler ATH, can be seen in figure 5a, where the reinforcing fibers look quite clearly bound to the resin matrix [20-21]. ATH bound to the resin matrix looks like white granules around the reinforcing fiber (see figures $5 b$ and 6 ).

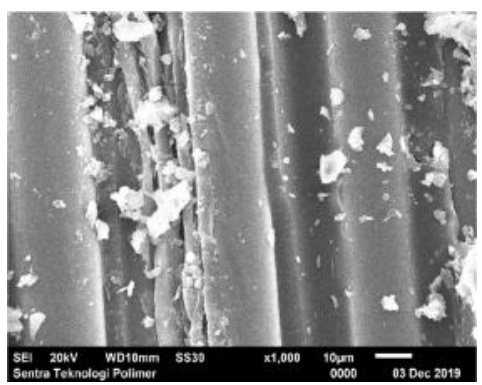

(a)

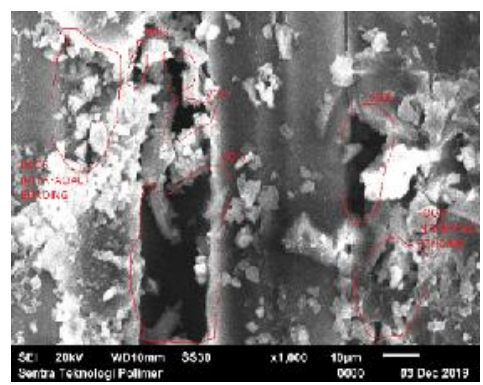

(b)

Figure 5. SEM Sample: (a) no.1 (non ATH) and (b) no.2 (10\% ATH). 


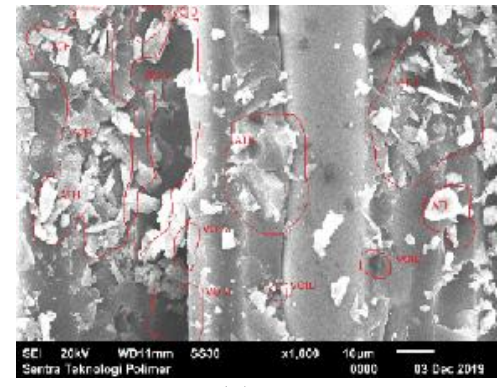

(a)

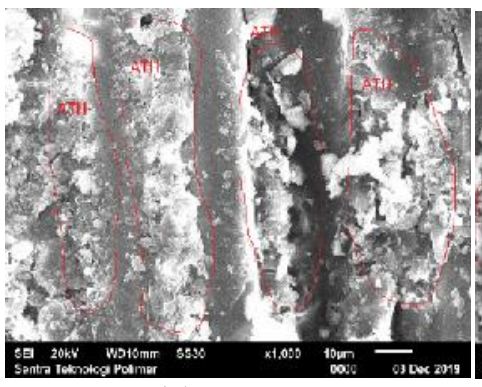

(b)

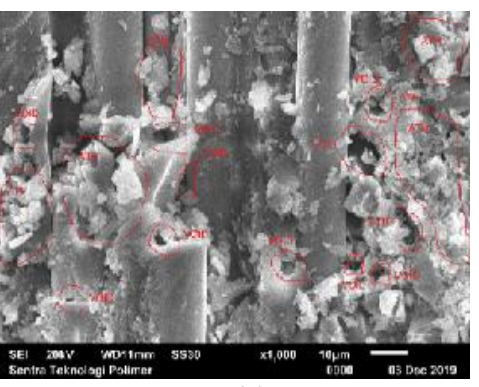

(c)

Figure 6. SEM Sample: (a) No.3 (15\% ATH), (b) No.4 (20\% ATH), (c) No.5 (25\% ATH).

The voids were also seen in all samples and the amount varies depending on the perfection of rolling during the lamination process. The better the rolling is done, the fewer the number of voids. Specifically, for sample No. 2 the number of voids was seen more than the other samples, so the data values of density, water absorption, and tensile strength were not as high as other samples.

The results of the density test are shown in figure 7, where sample no. 2 has a smaller density than sample no.1. Sample no. 3 has the same density as sample no.1, then sample no. 4 and no.5 have a density greater than sample no.1.

\begin{tabular}{|c|c|c|}
\hline No. Sample & Pevortape ATH & Destity if (mil) \\
\hline 1 & 6 & $153: 0002$ \\
\hline 2 & 18 & $15 \pm 000$ \\
\hline 3 & 155 & $159 \pm 001$ \\
\hline 4 & $\mathrm{x}$ & $258 \pm 007$ \\
\hline 5 & 255 & $199: 003$ \\
\hline
\end{tabular}

(a)

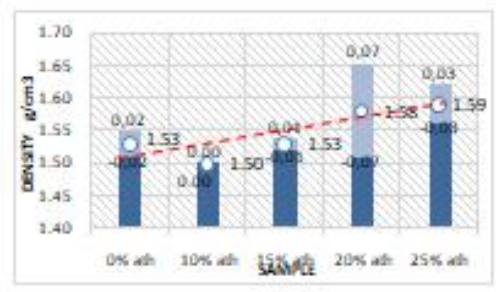

(b)

Figure 7. Testing Results: (a) Table of Density Testing Results and (b) Graph of Density Testing Results.

With the addition of filler samples to the resin, the density should also increase, as shown by the dashed red line shown in the graph in figure $7 \mathrm{~b}$ [11], because the density of ATH $\left(2.42 \mathrm{gr} / \mathrm{cm}^{3}\right)$ is greater than the density of the resin matrix $\left(1.05 \mathrm{gr} / \mathrm{cm}^{3}\right)$ [22]. There was a deviation in sample no.2 and no.3, where those samples have a smaller density than sample no.1. This can be caused by the voids formed during the lamination process of making the sample (see figure $5 \mathrm{~b}$ ). The voids, formed as a result of the lamination process, occurred due the manufacturing method of the test sample used, in which the method used is hand lay-up [23]. Based on ROM theory (rule of mixtures) it is known that [24]:

$$
\begin{aligned}
& \mathrm{Vc}=\mathrm{Vf}+\mathrm{Vm}+\mathrm{Vv} \\
& \text { where, } \mathrm{Vf}: \text { fiber volume fraction } \\
& \mathrm{Vm}: \text { matrix volume fraction } \\
& \mathrm{Vv}: \text { void volume fraction } \\
& \mathrm{Vc}: \text { composite volume fraction }
\end{aligned}
$$

The presence of voids will reduce the fiber volume fraction and matrix volume fraction [24]. And for sample no.4 and sample no.5, there was no deviation because the density value was greater than sample no.1. 
The results of the water absorption test are shown in figure 8, where sample no. 2 and no. 3 had a smaller water absorption value than sample no.1. Sample no.4 and no.5 had a greater water absorption value than sample no.1. With the addition of filler samples to the resin the water absorption should also increase, as shown by the dashed red line shown in the graph in Figure 8b. This is because if we cut the surface, the cut area contains a resin matrix and filler in addition to the reinforcing fibers. When the filler comes into contact with dew air/ water vapour, the water will be absorbed by the filler [25]. But it is different from what happened in sample no.2 and no.3, where the water absorption value is lower than sample no.1. This is, because the void volume fraction and the matrix volume fraction on the surface of the laminate layer are greater than the filler volume fraction, so the water absorption value is low [26-27]. And for sample no.4 and no.5, the water absorption value is greater than sample no.1. This is appropriate because with the addition of the ATH filler, the water absorption value will also be up [25]. As explained in the Figure 1, the structural layer on the GFRP tank body was given an external layer with a thickness max of $0.2 \mathrm{~mm}$ on the outside of the tank body so that the water vapour or liquid from the outside environment will not be in direct contact with the structural layer on the tank body GFRP [6, 8].

\begin{tabular}{|c|c|c|}
\hline la. Sample & Pesurbe ATH & Kasab Wrat (S) \\
\hline 1 & $\mathrm{dr}$ & $0175: 0005$ \\
\hline 2 & $2 \pi$ & $0165: 00080$ \\
\hline 3 & IB & $015 \times 5: 00013$ \\
\hline 4 & W & $01551: 00658$ \\
\hline 5 & 25 & 017):01000 \\
\hline
\end{tabular}

(a)

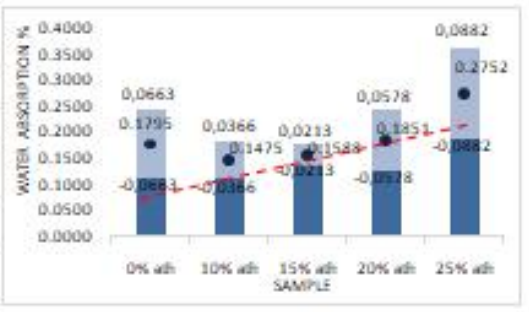

(b)

Figure 8. Water Absorption Testing Results: (a) Table Testing Results and (b) Graph Testing Results.

For all samples, the absorption of water that occurs is most likely to enter through the cuttings in the sample. If it functions as a tank, it is very difficult for liquid to penetrate through the chemical layer in the GFRP tank because there is a layer of pure resin before surfacing veils. Likewise in the structural layer, as there is a coating layer or surfacing veil given to the outside of the GFRP tank (in detail can be seen in figure 1) [9]. In Table 3, it is shown that the permissible water absorption value in the GFRP tank based on JIS K 6919 standard must be less than 1\% [28], so all samples meet the requirements for the value of water absorption.

Based on the results of the tensile strength test, the average tensile strength value is $200.5 \mathrm{MPa}$ for sample no.1, the average tensile strength value is $186.91 \mathrm{MPa}$ for sample no.2, the average tensile strength value is $202 \mathrm{MPa}$ for sample no.3, the average tensile strength value is $221.07 \mathrm{MPa}$ for sample no.4, the average tensile strength value is $198.7 \mathrm{MPa}$ for sample no.5 (see figure 9).

\begin{tabular}{|c|c|c|c|}
\hline \multirow{2}{*}{ sent } & \multicolumn{3}{|c|}{ Vateshestepher } \\
\hline & best & stect & kene? \\
\hline 1 & IST & 2900 & 305 \\
\hline 2 & $\pi: 30$ & 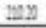 & $26 \mathrm{~s}$ \\
\hline 3 & 1560 & $20 x$ & $z x$ \\
\hline i & 73.30 & 280 & 210 \\
\hline 5 & 2120 & 512 & 30 \\
\hline
\end{tabular}

(a)

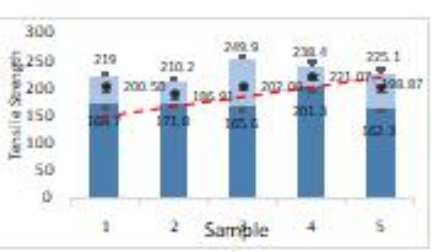

(b)

Figure 9. Tensile Strength Testing Results: (a) Table Testing Results and (b) Graph Testing Results. 
From all samples that were carried out the tensile strength test, it was known that the sample no. 2 had the lowest tensile strength value of $186.91 \mathrm{MPa}$ and sample no.4 had the highest tensile strength value of 221.077 MPa. A decrease in tensile strength value in sample no. 2 is caused by voids (cavities/ air bubbles) that are formed during the process of making test samples using the hand lay-up method [23]. The presence of voids will reduce the fiber volume fraction and matrix volume fraction, thereby causing a decrease in the stiffness and strength of the composite [24]. Stiffness and strength of the composite had decreased by voids due to lack of bonding between surfaces in the reinforcing fibers with a resin matrix [29]. Figure 5b shows that many voids formed due to air trap during the process of making the test sample. For sample no.3 and sample no.4, there was an increase in the value of tensile strength because the force applied to the test specimen during the tensile strength testing process, is accepted by the resin matrix and then passed by the resin matrix to the ATH filler, in addition to the reinforcing fiber, where the ATH filler functions like a reinforcing fiber as well [12, 30-31]. There is a strong bonding on the surface of the layer between the resin matrix with the ATH filler and the reinforcing fibers. The ATH fillers contained in the resin matrix also function as reinforcing fibers, accepting load transfers from the resin matrix (see figure 6a and 6b) [13]. And for sample no.5, the tensile strength value had decreased because with the addition of more fillers to the resin matrix, it will cause more voids, thereby reducing the tensile strength due to the low bonding between the surface layers (see figure 6c) [27, 29]. Physical and mechanical properties in GFRP tank can be seen in the table 3 .

Table 3. Physical and Mechanical Properties of GFRP Tank base on JIS Standard [28]

\begin{tabular}{l|c|c}
\hline \multicolumn{1}{c|}{ Property } & Performance & Testing Method \\
\hline Tensile strength & $>59 \mathrm{~N} / \mathrm{mm}^{2}$ & JS K 7054 \\
Flexural strength & $>78 \mathrm{~N} / \mathrm{mm}^{2}$ & JS K 7055 \\
Flexural modulus & $>5.9 \times 10^{3} \mathrm{~N} / \mathrm{mm}^{2}$ & JS K 7055 \\
Glass content & $>25 w \mathrm{wt} \%$ & JS K 7052 \\
Barcol hardness & $>30$ & JS K 7060 \\
Water absorption & $<1.0 \%$ & JS K 6919 \\
\hline
\end{tabular}

The mechanical properties of the GFRP tank, shown in table 3, show that the allowable tensile strength values must be above $59 \mathrm{~N} / \mathrm{mm} 2$ or $59 \mathrm{MPa}$ [28], so all samples qualify according to their tensile strength values. The use of ATH into a $25 \mathrm{wt} \%$ resin matrix as a filler is still considered safe, but if it is above $25 \mathrm{wt} \%$ it will complicate the process of wetting the resin matrix on the reinforcing fibers in the filament winding process of making GFRP chemical strorage tanks [5]. In addition, excess use of the filler in the resin matrix will also increase the viscosity of the resin matrix. Consequently, it is more difficult to remove trapped air during the mixing process of the resin matrix with the filler, which will later cause voids [22].

\section{CONCLUSIONS}

This paper describes the effect of alumina tri-hydrate $\mathrm{Al}(\mathrm{OH})_{3}$ fillers in vinylester resin. The testing samples is designed using different composition of ATH in the vinylester resin matrix as much $0 \mathrm{wt} \%, 10 \mathrm{wt} \%, 15 \mathrm{wt} \%, 20 \mathrm{wt} \%, 25 \mathrm{wt} \%$. The results were obtained after testing the physical and mechanical properties of 5 test samples. It is found that the addition of ATH to the vinylester resin increases density, water absorption and tensile strength.

The use of $0 \mathrm{wt} \%, 10 \mathrm{wt} \%, 15 \mathrm{wt} \%, 20 \mathrm{wt} \%, 25 \mathrm{wt} \%$ ATH fillers in the vinylester resin matrix was successfully carried out. All are able to be used with the consideration that the filler ATH $25 w \mathrm{w} \%$ is still able to be used and applied in the structure layer filament winding in the GFRP tank production process. The mechanical and physical characteristics of 
the sample with a composition of $75 \%$ / $25 \%$ has a tensile strength of $198.87 \mathrm{MPa}$, a density of $1.59 \mathrm{gr} / \mathrm{cm} 3 \mathrm{and}$ a water absorption of $0.2752 \%$.

\section{ACKNOWLEDGEMENT}

Special thanks to Mr.Yansen Budiman, President Director and Mr. Ahmad Rojak, Production Director of PT Diwan Budi Perkasa - Indonesia, for allowing authors to use company facilities to conduct the research.

\section{REFERENCES}

1. Varvani, A. and Farahani., Composite materials: characterization, fabrication and application research challenges and directions, Springer, Toronto-Canada, 2010, pp. 63-67.

2. Agarwal, B.D., Broutman, L.J and Chandrashekhara, K., Analysis and performance of fiber composites, Third edition, John Wiley\&Sons,Inc, USA, 2006.

3. American composites manufacturers association, Guidelines and recommended practice for fiber reinforced polymer (FRP) architectural products, ACMA, USA, 2016.

4. Andre, M.,Siguret, D., and Foulon, A., Corrosion evaluation of glass fiber reinforced plastic(GFRP) tanks \& pressure vessels using acoustic emission technology, $31^{\text {st }}$ Conference of the European working group on Acoustic Emission/EWGAE, France, 2014.

5. Budiman, Y., Interviewee, President Director PT. Diwan Budi Perkasa, Interview 5 December 2019.

6. Usmani, M. and Shinde, D.K., Characteristic and failure analysis of FRP composite tank used sodium hypochlorite(NaOCL) strorage, International research journal of engineering and technology/IRJET, Mumbai, 2018, vol.05, pp 1417-1422.

7. ASTM D3299-00, Standard specification for filament wound glass fiber reinforced thermoset resin corrosion resistant tanks, Annual book of ASTM Standards, vol.08.01, American Society for Testing and Materials(ASTM), Philadelphia, USA, 2000.

8. BS 4994, British standard specification for design and construction of vessels and tanks in reinforced plastics, BSI, UK, 1987.

9. Tiwari, A. and Torgal, S., Optimization in the design of fiber reinforced plastic storage tank, International journal of scientific\&technology research, vol.8, 2109, pp.1093-1097.

10. Beetle plastics, Chemical processing ebook: FRP applications, opportunities and solutions, Beetle plastics, USA, 2013.

11. Duan, Z., Tensile, quasistatic and dynamic fracture properties of nano $\mathrm{AL}_{2} \mathrm{O}_{3}$ modified epoxy resin, MDPI journal, China, 2018 .

12. Sathiyamurthy, S., Thaheer, A. S. A., and Jayabal, S., Modelling and optimization of mechanical behavior of $\mathrm{AL}_{2} \mathrm{O}_{3}$ coir polyester composites using response surface methodology, Indian journal of engineering\&materials sciences, India, 2013, vol.20, pp.59-67.

13. Prabhu, B. D., Ramesh, A., and Venkatesh, J., Experimental investigation and analysis of mechanical properties of polyvinyl ester/glass fiber composite with alumina $\left(\mathrm{AL}_{2} \mathrm{O}_{3}\right)$, molybdenum disulfide $\left(\mathrm{MOS}_{2}\right)$ and titanium oxide $\left(\mathrm{TIO}_{2}\right)$ fillers, International journal of mechanical and production engineering research and development /IJMPERD, India, 2018, vol.8, pp.125-134.

14. Setyanto, D., Jamasri, Suhendro, B. and Tontowi, A. E., Alumina as a filler in UPR matrix for FRP composite roofing sheets, International journal of materials science, 2012, vol.7 no.3, pp.191-202.

15. Petersen, M. R., Chen, A., Roll, M., Jung, S. J., and Yosef, M., Mechanical properties of fire retardant glass fiber reinforced 
polymer materials with alumina tri hydrate filler, Elsevier, 2015, Composite part B, vol.78, pp.109-121.

16. Kaleg, S., Ariawan, D., and Diharjo, K., The flexural strength of glass fiber reinforced polyester filled with alumunium tri hydroxide and Montmorillonite, Trans tech publications, Switzerland, 2018, vol.772, pp.28-32.

17. ASTM D1622-03, Standard test method for apparent density of rigid cellular plastics, Annual book of ASTM Standards, vol.08.01, American Society for Testing and Materials(ASTM), Philadelphia, USA, 2003.

18. ASTM D570-98, Standard test method for water absorption of plastics, Annual book of ASTM Standards, vol.08.01, American Society for Testing and Materials (ASTM), Philadelphia, USA, 1998.

19. ASTM D 638-00, Standard test method for tensile properties of plastics, Annual book of ASTM Standards, vol.08.01, American Society for Testing and Materials (ASTM), Philadelphia, USA, 2000.

20. Kim, Y. S., Kim, J. K., and Jeon, E. S., Effect of the compounding conditions of polyamide 6, carbon fiber, and $A L_{2} \mathrm{O}_{3}$ on the mechanical and thermal properties of the composite polymer, MDPI journal, 2019.

21. Kim, Y. S., Kim, J. K., Na, S. J., and Jeon, E. S., Experimental analysis on the application of polymer matrix composites containing $\mathrm{AL}_{2} \mathrm{O}_{3}$ for automotive lamp reflector, MDPI journal, 2019.

22. Jumahat, A., Haris, N. A., and Mohamad, F. N. C., Slurry pot erosion wear of nanoclay modified short fiber reinforced polymer(SFRP) composites, International journal of engineering and advanced technology(IJEAT), 2019, vol.9 issue 1,pp. 5832-5838.

23. Thakur, S. and Chauhan, S. R., Study on mechanical and tribologicalbehavior of cenosphere filled vinylester compositestaguchi method, Indian journal of engineering \& materials sciences, 2013, vol.20, pp.539-548.

24. Jones and Milard, R., Mechanic of composite materials, 2nd ed., Taylor and Francis Inc.Philadelphia, USA, 1999.

25. Wypych, G., Handbook of filler, 4th edition, Wiley-VCH VerlagGmbH\&Co., Weinheim, 2010.

26. Sampath, P. and Santhanam, S. K. V., Effect of moringa and bagasse ash filler particles on basalt/epoxy composites, Polimeros journal, 2019.

27. Swathi, A., S. Bhanu Murthy, and K. NagendraBabu, Evaluation of mechanical properties of GFRP composites with filler, International journal of innovative technology and exploring engineering(IJITEE), 2019, vol.8 issue 11, pp.3997-4001.

28. Sub-committee for design of strorage tanks, Design recommendation for strorage tanks and their supports with emphasis on seismic design, 2010 edition, Architectural institute of Japan.

29. Rathinasabapathi, G. and Krishnamoorthy, A., Exploration of nanofillers(multi walled carbon nano tubes and graphene powders) in the reinforcement of epoxy/glass fibre polymers(GFRP), International journal of innovative technology and exploring engineering, 2019, vol.8 issue 12, pp.2718-2722.

30. Setyanto, D., The possibility of E-glass woven roving as reinforcement of GFRP composite sheet roof, AIP, 2016, pp. 040007-1 - 040007-7.

31. Ouyang, Y., Ding, F., Bai, L., Li, X., Hou, G., Fan, J., and Yuan, F., Design of network $A L_{2} \mathrm{O}_{3}$ spheres for significantly enhanced thermal conductivity of polymer composites, Elsevier, 2020, Composites part A 128. 


\section{AUTHORS PROFILES}

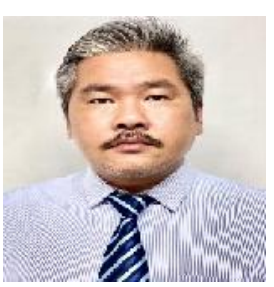

Deswan received his Bachelor degree in Mechanical Engineering from Atma Jaya Catholic University of Indonesia, Jakarta, Indonesia, and his Master degree in Management from Christian University of Krida Wacana, Jakarta, Indonesia. He is also an industry practitioner in composite materials GFRP tank manufacturing company in Tangerang Indonesia as President Commissioner. His main research interests deal with the experimental polymer matrix composites.

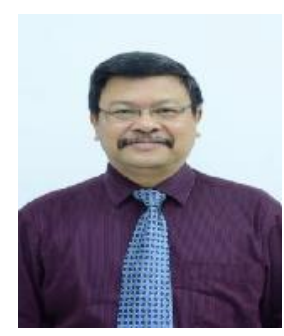

Djoko Setyanto received his Ph.D in Mechanical Engineering from Gadjah Mada University, Yogyakarta, Indonesia, and is currently as Researcher and Associate Professor at Department of Mechanical Engineering Atma Jaya Catholic University of Indonesia, Jakarta, Indonesia. He teaches variety of Engineering units including Strength of Materials, Theoretical and Experimental Mechanics, Vibrations, Engineering Design, and Polymer Matrix Composites. He is also an industry practitioner in polymer materials roofing sheet manufacturing company in Tangerang - Indonesia as the leader of a product development research team. His main research interests deal with the experimental mechanics, engineering product development, and polymer/ polymer matrix composites. 
